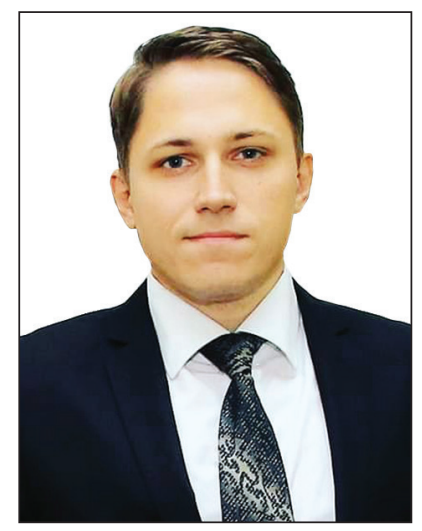

\author{
Shpak Maksym Volodymyrovych, \\ PhD in Law, \\ Assistant Professor of the Department \\ of Civil Procedure, \\ Yaroslav Mudryi National Law University, \\ Ukraine, Kharkiv \\ e-mail:maximshpak93@gmail.com \\ ORCID 0000-0003-2119-3828
}

doi: $10.21564 / 2414-990 x .150 .208013$
UDC 347.921 .8

\title{
THE PROBLEMATIC ISSUES OF LEGAL AID IN CASES CONSIDERED IN CIVIL PROCEEDINGS
}

The scientific article studies the issue of providing legal aid in cases which are considered in civil proceedings. The author pays attention to the existing scientific points of view of legal assistance in civil cases. Attention is drawn to the existing projects of law which are registered on the official website of the Verkhovna Rada of Ukraine, which propose significant changes to national legislation governing the institution of legal aid in cases pending in civil proceedings. The author draws attention to the functioning of the institute of free legal aid. The scientific article drazes attention to the exemplary practice with the participation of free lawyers as professional representatives in the case. The author's proposals on the possible update of the national civil procedural legislation are formulated which regulates the issue of providing legal aid in cases considered in civil proceedings.

Keywords: Legal aid; Civil process; Civil proceedings; Civil cases; Lawyer; Representation; COVID-19.

Шnак M. B., кандидат юридичних наук, асистент кафедри цивільного процесу, Національний юридичний університет імені Ярослава Мудрого, Україна, м. Харків.

e-mail: maximshpak93@gmail.com ; ORCID 0000-0003-2119-3828

Проблемні питання правової допомоги у справах, що розглядаються у цивільному судочинстві

Наголошено, що проблематика надання правової допомоги у справах, які розглядаються у порядку цивільного судочинства, завжди було важливим питанням науки та практики. Основні зачатки інституту реалізації, а також надання правової допомоги у різних категоріях справ (спорів) були закладені ще в часи Стародавнього Риму. 3 поступовим розвитком цього інституту він суттєво удосконалився та еволюціонував. Як наслідок, це набуло відповідного відображення і в змісті правосуб'єктності осіб, які мають право надати правову допомогу.

Наголошено, що правова допомога є важливою передумовою доступності до правосуддя у справах, що розглядаються у порядку цивільного судочинства особами, які через певні причини не в змозі постійно чи тимчасово реалізувати свою цивільну процесуальну правосуб'єктність з метою представлення у суді своєі правової позиџї та захисту права чи інтересу. 
Підкреслено, що правова допомога як важливий інститут иивільного процесуального права безперечно пов'язаний із категорією представництва. Водночас можливістю надавати правову допомогу у иивільному прочесі наділені не тільки процесуальні представники, а й суд (суддя) в окремих випадках.

Акцентовано на тому, що важливим при дослідженні питання надання правової допомоги у справах, які розглядаються в порядку цивільного судочинства повинно бути врахування професійного та кваліфікованого рівня иієї юридичної допомоги. Проте варто визнати, що не завжди іне у всіх випадках на практиці правова допомога у справах, які розглядаються у порядку цивільного судочинства, має дійсно високопрофесійний характер і має якісний правовий результат. Причинами такого явища є зокрема такі: 1) неналежна практична підготовка суб'єкта надання правової допомоги; 2) недостатня глибина знань у відповідній спеціалізації з боку суб'єкта надання правової допомоги; 3) недостатня мотивація суб'єкта надання правової допомоги та ін.

Зроблено висновок, що питання надання правової допомоги у справах, які розглядаються у порядку иивільного судочинства, є одним із ключових при реалізації права на доступ до суду та доступності правосуддя в иілому. Водночас потребують додаткового дослідження проблеми узгодження національного законодавства, що регулюе інститут надання правової допомоги (у тому числі у справах, які розглядаються у порядку цивільного судочинства), з міжнародно-правовими системами та вимогами крізь призму євроінтеграційних прагнень Украйни. Акцентовано на наданні правової допомоги при реалізащії електронного правосуддя, особливо в момент упроваджених карантинних обмежень задля запобігання поширенню COVID-19.

Ключові слова: правова допомога; цивільний процес; цивільне судочинство; цивільні справи; адвокат; представництво; COVID-19.

Setting of the problem. The issue of providing legal aid in cases which are considered in civil proceedings by people who are interested in obtaining it, it has always been an important issue of science and practice. However, the main beginnings of the development of institution of realization, as well as the providing of legal aid in various categories of cases (disputes) were found in the days of Ancient Rome. Due to the gradual development of this institute, the last has significantly improved and evolved. As a result, this gained appropriate image and in the content of the humans' legal subjectivity who can provide legal aid. Furthermore, it also has an effect on the spreading of the list of documents which indicate about the existence of appropriate powers to provide such type of legal aid. An important issue in this block of civil procedural law is the subjective composition of the realization of procedure for providing and receiving legal aid as a fundamental human right.

In recent years, the problem of providing legal aid in cases considered in civil proceedings has significantly reformed. In this context, we are talking not only about the relevant legal acts of the Verkhovna Rada of Ukraine as the main legislative body of Ukraine, but also about the existence of certain registered legislative initiatives on the official website of the Verkhovna Rada of Ukraine, their purpose is the introduction of many amendments to existing legislation acts which regulate the principles of functioning and organization the institution of providing legal aid in cases pending in civil proceedings.

Considering the previous information, it is undoubtedly important to analyze and study the legislative innovations, and also legislative proposals that related to the realization of legal aid in cases pending in civil proceedings. 
Actuality of the research topic: The actuality of the research is explained by the urgent need to analyze new legislative provisions and also legislative proposals which are in the texts of scientific projects of subjects of legislative initiative concerning the practical problems of providing and receiving legal aid in cases pending in civil proceedings. In addition, explaining the importance of the study of such urgent issue, it is appropriate to emphasize its special social significance. This is particularly the case for the providing legal aid during the quarantine restrictions which were introduced with measures to prevent a spreading of coronavirus infection (COVID-19).

Analysis of recent research and publications: shows that some issues considered the providing of legal aid in cases pending in civil proceedings were the subject of scientific research on the pages of legal literature.

It should be noted that the study of the peculiarities of the legal aid realization in cases pending in civil proceedings, scientists paid attention in the field of law (legal) sciences, including: S. S. Bychkova, Y. V. Bilousov, T. B. Vilchyk, N. Y. Golubeva, K. V. Gusarov, I. O. Izarova, V. V. Komarov, S. O. Koroed and other jurists.

In the context, it is worth emphasizing the fairness of the view expressed in the legal literature that a person who receives free secondary legal aid in civil proceedings, he represents as a principal of his procedural rights and responsibilities designated by the Center for Free Secondary Legal Aid [1, p. 86]. Also there is an interesting point of view of I. Kozyakov and O. Govorukha that guaranteeing the right of person to receive a legal aid and in cases established by law, free legal aid, it is not only a constitutional and legal obligation of the state, but also following the international - legal obligations by Ukraine. According to these scholars, practice shows that the system of free legal aid is currently in its becoming period. In their opinion, the process of its institutionalization and legal regulation has not been completed yet, so the level of European standards for ensuring access to justice and the quality of legal services are not reached by it but this field needs to be improved [2, p. 114]. There is a logical view of Y. Prut that in connection with the development of legal relations and the deepening of their legal regulation of providing legal aid is an element of ensuring effective access to justice [3, p. 57].

$\mathrm{V}$. M. Isakova's opinion that the right to legal aid is one of the aspects of access to justice and the right to a fair court hearing [4, p. 408]. Also V. M. Isakova in another work logically notes that the right to legal aid is necessary and inalienable opportunity to receive a professional assistance in legal matters by established legal order [5, p. 60]. Interesting is the view of Y. T. Shramko that by its characteristic the right to legal aid is a constitutional human right on receiving state-guaranteed qualified legal assistance, including free, in the realization of it, as a participant in the legal process, his legal status [6, p. 13]. It seems an interesting view of V. S. Lychko that the providing of legal aid in civil cases requires not only the development of clear mechanism for obtaining it, establishing situations and criteria for its providing but also in general the formulation of the definition of legal aid in civil cases [7, p. 533]. It is worth noting S. V. Overchuk's remark that the formation of a new concept of free legal aid, combined with the reform of bar, has created many legal 
problems, the solution of which is controversial among scholars, lawyers and officials. According to scientist, an important place in this discourse is the problematic question, who has the right and can receive legal aid from the budget [8, p. 1-2]. It should also be noted that attention to the study of legal aid in civil cases was paid to the famous scientist of civil procedural law by professor K. V. Gusarov [9, p. 140; 10, p. $124 ; 11$, p. $68 ; 12$, p. 200; 13, p. 199].

In the context of the study, the issue of providing free legal aid, it is appropriate to pay attention to the statistics indicated on the official website of the Cabinet of Ministers of Ukraine. Thus, in 2018, 623.8 thousand applications were executed in the centers of the free legal aid system, as well as 221 thousand calls to the single contact center [14].

At the same time, the problem of providing legal aid in cases which are considered in civil proceedings is not sufficiently studied. Scientific approaches concerning its realization need additional understanding and also the practice of its application. There is a special need and timeliness of its study.

The purpose of the article: research and analyze the problem of providing legal aid in cases pending in civil proceedings. An additional purpose is to express the author's views concerning proposals for potential changes to national legislation which regulates the principles of realization, as well as obtaining the legal aid by participants in civil proceedings relations.

Summary of the main material: Legal aid is an important prerequisite for access to justice in cases pending in civil proceedings by bodies who due to the relevant reasons, cannot permanently or temporarily realize their civil procedural legal personality in order to present their legal position and protection of right or interest in court .

Legal aid as an important institution of civil procedural law is undoubtedly connected with category of representation. At the same time, the opportunity to provide legal aid in civil proceedings is endowed not only with procedural representatives, but also with the court (judge) in some cases.

It is also important in the study of the providing legal aid in cases that are considered in civil proceedings should be taking into account the professional and qualified level of this legal aid. However, it should be recognized that not always and not in all cases in practice legal aid considered in civil proceedings is really highly professional and is characterized by a high-quality legal result. The reasons for this phenomenon can be understood as follows: 1) improper practical preparation of the subject who provides legal aid; 2) insufficient depth of knowledge in the appropriate specialization from side of subject who provides legal aid; 3) insufficient motivation of the subject who provides legal aid.

In the aspect of research of problem of civil procedural law, it should be emphasized that the main normative acts which regulate the issues of the providing legal aid in cases considered in civil proceedings is the Legal Act of Ukraine «On Free Legal Aid» (of 02.06.2011) [15], as well as the Legal Act of Ukraine «On Bar and Lawyer's Activity» (of 05.07.2012) [16]. 
Reflecting the problems of providing legal aid in cases that are considered in civil proceedings, the presence of a number of projects of law are paid attention and proposed concerning amendments to national legislation of Ukraine, which regulates the institution of legal aid.

There is a positive, noted point of view, since 2019 the legislative initiative was intensified activities to implement issues of improving international cooperation on legal aid by authority.

In this context, we are talking about the following documents: the Legal Act of Ukraine «On Ratification of the Agreement between Ukraine and the Federative Republic of Brazil on Mutual Legal Aid and Legal Relations in Civil Cases» of 14.01.2020 [17]; Draft Law «On Ratification of the Agreement between Ukraine and the Kingdom of Morocco on Legal Aid in Civil and Commercial Cases» № 0042 of 16.06.2020 [18]; Draft Law «On Ratification of the Agreement between Ukraine and the Hashemite Kingdom of Jordan on Mutual Legal Aid in Civil Cases» № 0047 of 16.06.2020 [19]. In recent years, the development of projects of law on the protection of rights and interests of certain categories of subjects who receives legal aid have been paid attention by the subjects of the legislative initiative. In this context, the following projects of law should be mentioned: 1) Draft Law "On Amendments to Article 14 of the Legal Act of Ukraine "On Free Legal Aid" (for Residents of Temporarily Occupied Territories)” № 2015 of September 3, 2019 [20]; 2) Draft Law «On Amendments to the Legal Act of Ukraine «On Free Legal Aid» to ensure the right of bodies illegally deprived of personal liberty to free secondary legal aid» № 2056 of 04.09.2019 [21]; 3) Draft Law «On Amendments to certain legal acts of Ukraine concerning simplification of access to Free Legal Aid for children and bodies with disabilities and improvement of the quality of its prividing” № 2704 of December 28, 2019 (but on March 4, 2020, the draft was withdrawn) [22].

Also, as a positive phenomenon, it should be noted that in 2020 there is a new competition for the selection of lawyers for the system of free legal aid, which is appropriate to Instruction of the Ministry of Justice of Ukraine [23]. In this regard, it is necessary to emphasize the active participation in the evaluation of candidates in this competition by scientific - pedagogical employees of leading national higher education institutions, including the head of Poltava Law Institute Yaroslav Mudryi National Law University (Poltava, Ukraine) O. M. Lemeshko [24]. The author of this scientific article hopes that holding such competitions should positively contribute to the development of the following areas: 1) improving the functioning of the institution of free legal aid, including in cases that are considered in civil proceedings; 2) improving the functioning of the bar as a non-governmental institution; 3) improving the access to justice for bodies who need to receive appropriate legal support in the form of legal aid.

According to information data, 799 people were selected for the free legal aid system based on the results of the competition held in 2020 for the selection of lawyers. In general, according to information of 06.07.2020 in the Register of lawyers who provide free legal aid, there are 7553 lawyers [25]. 
At the same time, when considering the legal practice of providing free qualified legal aid, it is worth paying attention to the situation in the dwelling dispute, in which a lawsuit was filed to recognize citizens, those who lost the right to use housing and eviction. This case was essential during the long period of time. After the consultations, the lawyers developed and submitted reviews and objections to the court and represented the interests of the clients in the trial court. But the trial court decided to evict the family from the house. The lawyers appealed the decision of the trial court to the Khmelnytsky Court of Appeal. The lawyers argued that trial court did not take into account the fact that the clients have lived in the disputed house for more than 15 years by mutual consent, they concluded utility contracts and paid for them and also they intended to repaire the house. Following the review of the appeal by the appellate court, the decision of trial court was overturned and a new decision was issued refusing the plaintiffs in the case to satisfy the eviction claims, as well as the right of clients living in the house [26]. Taking into account such an exemplary case from the legal practice of lawyers, it is necessary to emphasize the need for supporting other lawyers to observe the same professional level in other practical situations (regardless of specialization or legal direction). Lawyers, as subjects of legal (professional legal) aid must always fight for the effective protection of the rights and interests of their clients (including in cases that are considered in civil proceedings).

In order to conduct an expanded study of the problems of providing legal aid in cases considered in civil proceedings, it is advisable to analyze the registered legislative proposals on the official website of the Verkhovna Rada of Ukraine.

However in accordance with the provisions of Part 1 of Art. 19 CPC of Ukraine (of 18.03.2004), courts consider in the order of civil proceedings cases arising from civil, land, labor, family, dwelling and other legal relations, except for cases which consideration carried out in the order of other proceedings [27], is interesting to analyze the Draft Law «On Amendments to Article 5 of the Legal Act of Ukraine «On Judicial Fees» on exemption from court fees for filing claims for requirements arising from labor relations» № 3647 of 12.06.2020 [28].

In accordance with the current version of paragraph 1, part 1 of Art. 5 of the Legal Act of Ukraine «On court fees» (of 08.07.2011), from the payment of court fees during the proceedings in all courts are exempt plaintiffs - in cases of recovery of wages and reinstatement at work [29]. And according to the proposals contained in the mentioned project of law № 3647, it is proposed to expand the list of privilege from cases of exemption from court fees in respect of other cases than wage collection and reinstatement at work. In fact, it is proposed to supplement paragraph 1 of Part 1 of Art. 5 of the Legal Act of Ukraine «On court fees» by the words: «... and other requirements arising from labor relations» [28].

Examining the prospects of such legislative proposals, it should be clarified that an important block of court cases which is considered in civil proceedings for labor specialization, there are cases of collection of wages, reinstatement at work, disputes connected with conclusion and termination of employment contracts 
(as civil legal agreements), cases related to unreasonable refusal to hire an employee etc.

Providing legal aid to clients in similar categories of cases, which are considered in civil proceedings, important stages of the subject's activity to provide such aid, there are the followings: 1) Consultations, which should include an actual discussion of strategic issues concerning the legal position of the legal representative in the case and its representation in the court; 2) Development and improvement of procedural documents in the case; 3) Payment of court fees as a type of court costs in the amounts specified by law; 4) Submission to the court of properly confirmed procedural documents and appendices to them; 5) Provision of legal aid (and in the case when a lawyer does it - professional legal aid) in the form of procedural representation in court.

In our opinion, in the case of the adoption of mentioned project of law № 3647, such a consequence is probable, when the number of cases on labor specialization may significantly increase due to the reduction of peculiar procedural filters which are court fees as types of court costs.

At the same time we will remind that according to instructions of Art. $131^{2}$ of the Constitution of Ukraine (dated 28.06.1996) only a lawyer represents another person in court, as well as protection from criminal charges. The legal act may determine for exceptions to the representation in court in labor disputes, disputes concerning the protection of social rights, elections and referendums, insignificant disputes, as well as the representation of minors and bodies are recognized as incapacitated or whose legal capacity is limited by court [30].

Considering the promising ways to improve the procedures for providing legal aid in cases that are considered in civil proceedings, in our opinion, it would be appropriate to change the current procedural legislation. As possible changes it is expedient, from our point of view, would be addition of p. 1 Art. 65 $\mathrm{CPC}$ of Ukraine previously existing norm on the person who provides legal aid in the case.

Substantiating such proposals, we believe that the introduction of such norm on the providing of legal aid in cases pending in civil proceedings would increase the importance and significance of status of person who provides legal aid. Because in a case that is considered in civil proceedings, it is possible to use not only legal aid (referred to in Art. 15 of the CPC of Ukraine), but also ordinary legal aid (that is provided to bodies who do not have the legal status of lawyer), it seems appropriate to predict a separate norm in the content of the CPC of Ukraine and the subject who provides legal aid.

In order to continue the mentioned, it would also be appropriate to restore in the content of the CPC of Ukraine a separate article on the person who provides legal aid in a case pending in civil proceedings. Edited by CPC of Ukraine, for example, on August 3, 2017, Art. 56 entitled: «The person who provides legal aid» established the basic principles of mentioned subject of civil procedural legal relations. 
Conclusions. Therefore, it should be recognized that the issue of providing legal aid in cases considered in civil proceedings is one of the key issues in the realization of right of access to court and access to justice in general. At the same time, they need additional research on the issue of harmonization of national legislation governing the institution of providing legal aid (including cases pending in civil proceedings) with international legal systems and requirements through the Ukraine's European integration ambitions. The particular part in this context is the providing of legal aid in the administration of e-Justice, especially at the time of the introduction of quarantine restrictions which are connected with measures to prevent spreading of COVID-19. These and other issues will be explored by the author of this scientific article in other works on the pages of legal literature.

\section{Список літератури}

1. Право особи на безоплатну правову допомогу / Ю. О. Данилевська, Л. В. Павлик, 3. 3. Петрович, У. О. Цмоць. Львів: ЛьвДУВС, 2018. 136 с. URL: http://nbuviap.gov.ua/images/ dorobku_partneriv/Pravo\%20osoby\%20na\%20bezoplatnu\%20pravovu\%20dopomohu.pdf (дата звернення: 11.07.2020).

2. Козьяков І., Говоруха О. Актуальні питання реалізації принципів надання безоплатної правової допомоги. Науковий часопис Національної академії прокуратури України. 2018. № 1. C. 107-116. URL; http://www.chasopysnapu.gp.gov.ua/ua/pdf/1-2018/koziakov_govoruha.pdf (дата звернення: 11.07.2020).

3. Прут Ю. Інститут правової допомоги в цивільному судочинстві: цивільно-процесуальні особливості реалізації. Підприємництво, господарство і право. 2016. № 3. C. 54-58. URL: http:// pgp-journal.kiev.ua/archive/2016/03/10.pdf (дата звернення: 11.07.2020).

4. Ісакова В. М. Право на правову допомогу як елемент принципу доступності правосуддя. Форум права. 2012. № 4. C. 404-410. URL: http://dspace.nlu.edu.ua/bitstream/123456789/2055/1/ ISakova.pdf (дата звернення: 11.07.2020).

5. Ісакова В. М. Право на правову допомогу: до питання про визначення місця в системі прав людини. Актуальні проблеми державного будівництва та місцевого самоврядування в контексті конституційної модернізації : зб. наук. ст. за матеріалами наук-практ. семінару, м. Харків, 14 жовтн. 2016 р. C. 56-61. URL: http://dspace.nlu.edu.ua/bitstream/123456789/11505/1/Isakova. pdf (дата звернення: 11.07.2020).

6. Шрамко Ю. Т. Конституційне право на правову допомогу в Україні: актуальні питання законодавчого регулювання : автореф. дис. ... канд. юрид. наук. 2016. Київ. 19 с. URL: http:// idpnan.org.ua/files/shramko-yu.t.-konstitutsiyne-pravo-na-pravovu-dopomogu-v-ukrayini-_aktualnipitannya-zakonodavchogo-regulyuvannya_pdf (дата звернення: 11.07.2020).

7. Личко В. С. Правова допомога та її особливості в цивільних справах. Актуальні проблеми держави і права. 2012. № 63. C. 527-534. URL: http://www.apdp.in.ua/v63/80.pdf (дата звернення: 11.07.2020).

8. Оверчук С. В. Умови надання безоплатної правової допомоги в контексті прецедентної практики Європейського суду з прав людини. Часопис Наиіонального університету «Острозька академія». Серія «Право». 2016. № 1. С. 1-43. URL: https://lj.oa.edu.ua/articles/2016/n1/16osvzpl. pdf (дата звернення: 11.07.2020).

9. Гусаров К. В. Особливості окремої ухвали у цивільному судочинстві. Порівняльно-аналітичне право. 2013. № 2. С. 139-141. URL: http://dspace.nlu.edu.ua/bitstream/123456789/9614/1/ Gusarov_139_141.pdf (дата звернення 11.07.2020).

10. Гусаров К. В. Вступительный очерк к книге М. М. Михайлова «Избранные произведения». Вестник гражданского прощесса. 2017. № 3. С. 116-131. doi: https://doi.org/10.24031/22260781-2017-7-3-116-131. 
11. Гусаров К. В. Проблемы гражданской процессуальной правосубъектности : дис. ... канд. юрид. наук. Харків. 2000. 201 с.

12. Гусаров К. В. Інстанційний перегляд судових рішень у цивільному судочинстві : дис. ... д-ра. юрид. наук. Харків, 2011. 431 с.

13. Гусаров К. В. Перегляд судових рішень в апеляційному та касаційному порядках : монографія. Харків : Право, 2010. 352 с.

14. Система безоплатної правової допомоги в Україні. URL: https://www.kmu.gov.ua/news/ sistema-bezoplatnoyi-pravovoyi-dopomogi-v-ukrayini (дата звернення: 11.07.2020).

15. Про безоплатну правову допомогу : Закон України від 02.06.2011 p. URL: https://zakon. rada.gov.ua/laws/show/3460-17\#Text (дата звернення: 11.07.2020).

16. Про адвокатуру та адвокатську діяльність : Закон України від 08.07.2012 p. URL: https:// zakon.rada.gov.ua/laws/show/5076-17\#Tехt (дата звернення: 11.07.2020).

17. Про ратифікацію Договору між Україною та Федеративною Республікою Бразилія про взаємну правову допомогу та правові відносини у цивільних справах : Закон України від 14.01.2020 p. URL: https://zakon.rada.gov.ua/laws/show/452-20\#Tеxt (дата звернення: 11.07.2020).

18. Про ратифікацію Договору між Україною та Королівством Марокко про правову допомогу у цивільних і комерційних справах : проєкт закону від 16.06.2020 р. № 0042. URL: http:// w1.c1.rada.gov.ua/pls/zweb2/webproc4_1?pf3511=69150 (дата звернення: 11.07.2020).

19. Про ратифікацію Договору між Україною та Йорданським Хашимітським Королівством про взаємну правову допомогу у цивільних справах : проєкт закону від 16.06.2020 р. № 0047. URL: http://w1.c1.rada.gov.ua/pls/zweb2/webproc4_1?pf3511=69155 (дата звернення: 11.07.2020).

20. Про внесення доповнення до статті 14 Закону України «Про безоплатну правову допомогу» (щодо мешканців тимчасово окупованих територій) : проєкт закону від 03.09.2019 р. № 2015. URL: http://w1.c1.rada.gov.ua/pls/zweb2/webproc4_1?pf3511=66626 (дата звернення: 11.07.2020).

21. Про внесення змін до Закону України «Про безоплатну правову допомогу» щодо забезпечення права осіб, які незаконно позбавлені особистої свободи, на безоплатну вторинну правову допомогу : проєкт закону від 04.09.2019 р. № 2056. URL: http://w1.c1.rada.gov.ua/pls/zweb2/ webproc4_1?pf3511=66678 (дата звернення: 11.07.2020).

22. Про внесення змін до деяких законів України щодо спрощення доступу до безоплатної правової допомоги дітей та осіб з інвалідністю та підвищення якості її надання : проєкт закону від 28.12.2019 р. № 2704. URL: http://w1.c1.rada.gov.ua/pls/zweb2/webproc4_1?pf3511=67829 (дата звернення: 11.07.2020).

23. Про проведення конкурсу з відбору адвокатів, які залучаються для надання безоплатної вторинної правової допомоги : наказ Міністерства юстиції України від 17.01.2020 р. № 128/7. URL: https://legalaid.gov.ua/wp-content/uploads/2020/01/nakaz-konkurs-2020-1.pdf (дата звернення: 11.07.2020).

24. Директор Полтавського юридичного інституту О. М. Лемешко взяв участь у проведенні другого етапу XII конкурсу з відбору адвокатів до системи безоплатної правової допомоги. URL: http://pli.nlu.edu.ua/?p=14992 (дата звернення: 11.07.2020).

25. Ряди безоплатних адвокатів поповнили 799 юристів. URL: https://zib.com.ua/ua/143338ryadi_bezoplatnih_advokativ_popovnili_799_yuristiv.html?fbclid=IwAR27IpXus78VjGxp4qZl5W7 Ee53IoAciUpw9mGJCxBBNupjPt56Cga1Lxig (дата звернення: 11.07.2020).

26. Адвокати захистили сім'ю від виселення з житла. 11.05.2020 p. URL: https://denzadnem. com.ua/aktualno/56598 (дата звернення: 11.07.2020).

27. Цивільний процесуальний кодекс України від 18.03.2004 p. URL: https://zakon.rada.gov. ua/laws/show/1618-15\#Text (дата звернення: 11.07.2020).

28. Про внесення зміни до статті 5 Закону України «Про судовий збір» щодо звільнення від сплати судового збору за подання позовів за вимогами, що виникають із трудових правовідносин : проєкт закону від 12.06 .2020 р. № 3647. URL: http://w1.c1.rada.gov.ua/pls/zweb2/ webproc4_1?pf3511=69124 (дата звернення: 11.07.2020). 
29. Про судовий збір : Закон України від 08.07.2011 p. URL: https://zakon.rada.gov.ua/laws/ show/3674-17\#Tехt (дата звернення: 11.07.2020).

30. Конституція України від 28.06.1996 p. URL: https://zakon.rada.gov.ua/laws/show/254\% D0\% BA/96-\%D0\%B2\%D1\%80\#Tеxt (дата звернення: 11.07.2020).

\section{References}

1. Danylevska, Yu.O., Pavlyk, L.V., Petrovych, Z.Z., Tsmots, U.O. (2018). Pravo osoby na bezoplatnu pravovu dopomohu. Lviv: LvDUVS. URL: http://nbuviap.gov.ua/images/dorobku_ partneriv/Pravo\%20osoby\%20na\%20bezoplatnu\%20pravovu\%20dopomohu.pdf [in Ukrainian].

2. Koziakov, I., Hovorukha, O. (2018). Aktualni pytannia realizatsii pryntsypiv nadannia bezoplatnoi pravovoi dopomohy. Naukovyi chasopys Natsionalni akademii prokuratury Ukrainy Scientific journal of the National Academy of the Prosecutor's Office of Ukraine, 1, 107-116. URL: http://www.chasopysnapu.gp.gov.ua/ua/pdf/1-2018/koziakov_govoruha.pdf [in Ukrainian].

3. Prut, Yu. (2016). Instytut pravovoi dopomohy v tsyvilnomu sudochynstvi: tsyvilno-protsesualni osoblyvosti realizatsii. Pidpryiemnytstvo, hospodarstvo i pravo - Entrepreneurship, Economy and Lawe, 3 , 54-58. URL: http://pgp-journal.kiev.ua/archive/2016/03/10.pdf [in Ukrainian].

4. Isakova, V.M. (2012). Pravo na pravovu dopomohu yak element pryntsypu dostupnosti pravosuddia. Forum prava - Law forum, 4, 404-410. URL: http://dspace.nlu.edu.ua/ bitstream/123456789/2055/1/ISakova.pdf [in Ukrainian].

5. Isakova, V.M. (2016). Pravo na pravovu dopomohu: do pytannia pro vyznachennia mistsia v systemi prav liudyny. Aktualni problemy derzhavnoho budivnytstva ta mistsevoho samovriaduvannia $v$ konteksti konstytutsiinoi modernizatsii: zb. nauk. st. za materialamy nauk.-prakt. seminaru, m. Kharkiv, 14 zhovtn. $2016 r$. - Current issues of state building and local self-government in the context of constitutional modernization: Proceedings of the Scientific and Practical Conference. 56-61. URL: http://dspace.nlu.edu.ua/bitstream/123456789/11505/1/Isakova.pdf [in Ukrainian].

6. Shramko, Yu.T. (2016). Konstytutsiine pravo na pravovu dopomohu v Ukraini: aktualni pytannia zakonodavchoho rehuliuvannia. Extended abstract of candidate's thesis. Kyiv. URL: http:// idpnan.org.ua/files/shramko-yu.t.-konstitutsiyne-pravo-na-pravovu-dopomogu-v-ukrayini-_aktualnipitannya-zakonodavchogo-regulyuvannya_.pdf [in Ukrainian].

7. Lychko, V.S. (2012). Pravova dopomoha ta yii osoblyvosti v tsyvilnykh spravakh. Aktualni problemy derzhavy i prava - Current issues of state and laze, 63, 527-534. URL: http://www.apdp. in.ua/v63/80.pdf [in Ukrainian].

8. Overchuk, S.V. (2016). Umovy nadannia bezoplatnoi pravovoi dopomohy v konteksti pretsedentnoi praktyky Yevropeiskoho sudu z prav liudyny. Chasopys Natsionalnoho universytetu «Ostrozka akademiia». Seriia «Pravo» - Journal of the National University "Ostroh Academy”. Law Series, 1, 1-43. URL: https://lj.oa.edu.ua/articles/2016/n1/16osvzpl.pdf [in Ukrainian].

9. Gusarov, K.V. (2013). Osoblyvosti okremoi ukhvaly u tsyvilnomu sudochynstvi. Porivnialnoanalitychne pravo - Comparative and analytical law, 2, 139-141. URL: http://dspace.nlu.edu.ua/ bitstream/123456789/9614/1/Gusarov_139_141.pdf [in Ukrainian].

10. Gusarov, K.V. (2017). Vstupitel'nyj ocherk k knige M. M. Mihajlova «Izbrannye proizvedeniya» [Introductory Review to the M. M. Mikhailov's Book «Selected Works»]. Herald of Civil Procedure, 3, 116-131. doi: https://doi.org/10.24031/2226-0781-2017-7-3-116-131 [in Russian].

11. Gusarov, K.V. (2000). Problemi hrazhdanskoi protsessualnoi pravosubjektnosty. Candidate's thesis. Kharkiv [in Russian].

12. Gusarov, K.V. (2011). Instantsiinyi perehliad sudovykh rishen u tsyvilnomu sudochynstvi. Doctor's thesis. Kharkiv [in Ukrainian].

13. Gusarov, K.V. (2010). Perehliad sudovykh rishen v apeliatsiinomu ta kasatsiinomu poriadkakh. Kharkiv: Pravo [in Ukrainian].

14. Systema bezoplatnoi pravovoi dopomohy v Ukraini. URL: https://www.kmu.gov.ua/news/ sistema-bezoplatnoyi-pravovoyi-dopomogi-v-ukrayini [in Ukrainian]. 
15. Pro bezoplatnu pravovu dopomohu: Zakon Ukrainy vid 02.06.2011 r. URL: https://zakon. rada.gov.ua/laws/show/3460-17\#Text [in Ukrainian].

16. Pro advokaturu ta advokatsku diialnist: Zakon Ukrainy vid 08.07.2012 r. URL: https://zakon. rada.gov.ua/laws/show/5076-17\#Text [in Ukrainian].

17. Pro ratyfikatsiiu Dohovoru mizh Ukrainoiu ta Federatyvnoiu Respublikoiu Brazyliia pro vzaiemnu pravovu dopomohu ta pravovi vidnosyny u tsyvilnykh spravakh: Zakon Ukrainy vid 14.01.2020 r. URL: https://zakon.rada.gov.ua/laws/show/452-20\#Text [in Ukrainian].

18. Pro ratyfikatsiiu Dohovoru mizh Ukrainoiu ta Korolivstvom Marokko pro pravovu dopomohu u tsyvilnykh i komertsiinykh spravakh: proekt zakonu № 0042 vid 16.06.2020 r. URL: http://w1.c1. rada.gov.ua/pls/zweb2/webproc4_1?pf3511=69150 [in Ukrainian].

19. Pro ratyfikatsiiu Dohovoru mizh Ukrainoiu ta Yordanskym Khashymitskym Korolivstvom pro vzaiemnu pravovu dopomohu u tsyvilnykh spravakh: proekt zakonu № 0047 vid 16.06.2020 r. URL: http://w1.c1.rada.gov.ua/pls/zweb2/webproc4_1?pf3511=69155 [in Ukrainian].

20. Pro vnesennia dopovnennia do statti 14 Zakonu Ukrainy «Pro bezoplatnu pravovu dopomohu» (shchodo meshkantsiv tymchasovo okupovanykh terytorii): proekt zakonu № 2015 vid 03.09.2019 r. URL: http://w1.c1.rada.gov.ua/pls/zweb2/webproc4_1?pf3511=66626 [in Ukrainian].

21. Pro vnesennia zmin do Zakonu Ukrainy «Pro bezoplatnu pravovu dopomohu» shchodo zabezpechennia prava osib, yaki nezakonno pozbavleni osobystoi svobody, na bezoplatnu vtorynnu pravovu dopomohu: proekt zakonu № 2056 vid 04.09.2019 r. URL: http://w1.c1.rada.gov.ua/pls/ zweb2/webproc4_1?pf3511=66678 [in Ukrainian].

22. Pro vnesennia zmin do deiakykh zakoniv Ukrainy shchodo sproshchennia dostupu do bezoplatnoi pravovoi dopomohy ditei ta osib z invalidnistiu ta pidvyshchennia yakosti yii nadannia: proekt zakonu № 2704 vid 28.12.2019 r. URL: http://w1.c1.rada.gov.ua/pls/zweb2/webproc4_1?pf3511=67829 [in Ukrainian].

23. Pro provedennia konkursu z vidboru advokativ, yaki zaluchaiutsia dlia nadannia bezoplatnoi vtorynnoi pravovoi dopomohy: nakaz Ministerstva yustytsii Ukrainy № 128/7 vid 17.01.2020 r. URL: https://legalaid.gov.ua/wp-content/uploads/2020/01/nakaz-konkurs-2020-1.pdf [in Ukrainian].

24. Dyrektor Poltavskoho yurydychnoho instytutu O. M. Lemeshko pryiniav uchast u provedenni druhoho etapu XII konkursu z vidboru advokativ do systemy bezoplatnoi pravovoi dopomohy. URL: http://pli.nlu.edu.ua/?p=14992 [in Ukrainian].

25. Riady bezoplatnykh advokativ popovnyly 799 yurystiv. URL: https://zib.com.ua/ua/143338ryadi_bezoplatnih_advokativ_popovnili_799_yuristiv.html?fbclid=IwAR27IpXus78VjGxp4qZ15W7 Ee53IoAciUpw9mGJCxBBNupjPt56Cga1Lxig [in Ukrainian].

26. Advokaty zakhystyly simiu vid vyselennia z zhytla. 11.05.2020 r. URL: https://denzadnem. com.ua/aktualno/56598 [in Ukrainian].

27. Tsyvilnyi protsesualnyi kodeks Ukrainy vid 18.03.2004 r. URL: https://zakon.rada.gov.ua/ laws/show/1618-15\#Text [in Ukrainian].

28. Pro vnesennia zminy do statti 5 Zakonu Ukrainy «Pro sudovyi zbir» shchodo zvilnennia vid splaty sudovoho zboru za podannia pozoviv za vymohamy, shcho vynykaiut iz trudovykh pravovidnosyn: proekt zakonu № 3647 vid 12.06.2020 r. URL: http://w1.c1.rada.gov.ua/pls/zweb2/ webproc4_1?pf3511=69124 [in Ukrainian].

29. Pro sudovyi zbir: Zakon Ukrainy vid 08.07.2011 r. URL: https://zakon.rada.gov.ua/laws/ show/3674-17\#Text [in Ukrainian].

30. Konstytutsiia Ukrainy vid 28.06.1996 r. URL: https://zakon.rada.gov.ua/laws/ show $/ 254 \%$ D0\%BA/96-\%D0\%B2\%D1\%80\#Text [in Ukrainian].

Шилак M. B., кандидат юридических наук, ассистент кафедры гражданского процесса, Национальный юридический университет имени Ярослава Мудрого, Украина, г. Харьков.

e-mail: maximshpak93@gmail.com ; ORCID 0000-0003-2119-3828 


\section{Проблемные вопросы правовой помощи по делам, которые рассматриваются в граждан- ском судопроизводстве}

Исследуется проблематика оказания правовой помощи по делам, рассматриваемым в порядке гражданского судопроизводства. Уделяется внимание существуюшим научньм взглядам по вопросам оказания правовой помощи по гражданским делам. Анализируются законопроекты, зарегистрированые на официальном сайте (портале) Верховной Рады Украины, которыми предлагаются существенные изменения в отечественное законодательство, регулирующее вопросы института правовой помощи по делам, которые рассматриваются в порядке гражданского судопроизводства. Изложена примерная практика с участием бесплатных адвокатов как профессиональных представителей по делу. Сформулированы предложения по возможному обновлению национального гражданского прочессуального законодательства, регулирующего вопросы оказания правовой помощи по делам, которые рассматриваются в порядке гражданского судопроизводства.

Ключевые слова: правовая помощь; гражданский процесс; гражданское судопроизводство; гражданские дела; адвокат; представительство; COVID-19.

Рекомендоване цитування: Shpak M. V. The problematic issues of legal aid in cases considered in civil proceedings. Проблеми законності. 2020. Вип. 150. С. 78-89. doi: https://doi. org/10.21564/2414-990x.150.208013.

Suggested Citation: Shpak, M.V. (2020). The problematic issues of legal aid in cases considered in civil proceedings. Problemy zakonnosti - Problems of Legality, issue 150, 78-89. doi: https://doi. org/10.21564/2414-990x.150.208013.

Надійшла до редколегї 14.07.2020 p. 